\title{
The Lullaby of Ilse Weber: Terezín as a Mirror Image
}

\author{
Mirjam Frank
}

\section{Ilse Weber "Wiegala"}

Wiegala, wiegala, weier, der Wind spielt auf der Leier. Er spielt so süß im grünen Ried, die Nachtigall, die singt ihr Lied. Wiegala, wiegala, weier, der Wind spielt auf der Leier.

Wiegala, wiegala, werne, der Mond ist die Laterne, er steht am dunklen Himmelszelt und schaut hernieder auf die Welt. Wiegala, wiegala, werne, der Mond ist die Laterne.

Wiegala, wiegala, wille, wie ist die Welt so stille! Es stört kein Laut die süße Ruh, schlaf, mein Kindchen, schlaf auch du. Wiegala, wiegala, wille, wie ist die Welt so stille! ${ }^{30}$
Wiegala, wiegala, weier, the wind plays on the lyre. It's playing sweetly in the reeds, the nightingale sings her song. Wiegala, wiegala, weier, the wind plays on the lyre.

Wiegala, wiegala, werne the moon is the lantern, he looks down to earth from heaven's tent. Wiegala, wiegala, werne, the moon is the lantern.

Wiegala, wiegala, wille, how still the world is! No sound disturbs the sweet peace, sleep, my child, sleep. Wiegala, wiegala, wille, how still the world is! ${ }^{31}$

I would like to thank Professor Michael Beckerman for his encouragement and invaluable advice on the topic.

$30 \quad$ Ilse Weber, "Wiegala" (poem) in Ulrike Migdal, Ilse Weber: Wann wohl das Leid ein Ende hat, Briefe und Gedichte aus Theresienstadt (München: Carl Hanser Verlag, 2008), 268.

31 Translation: Mirjam Frank. 
According to the liner notes of the 2008 Deutsche Grammophon release Terezin, "Wiegala" was the last song Ilse Weber (1903-1944) sang together with a group of sick children, whom she had previously nursed in Terezín, while they were waiting for their death in the gas chambers of Auschwitz towards the end of $1944 .{ }^{32}$ It is likely that her second and youngest son, Tommy, was among these children.

The gas chambers of Auschwitz stand in stark contrast with the idea of a calming lullaby in general, and the words of Weber's "Wiegala" in particular: "Wie ist die Welt so stille! How still the world is!" The effect created by the juxtaposition is powerful. Yet, even a brief examination will show that this backdrop to "Wiegala", presumably written between 1942 and 1944 in Terezín, is a rather murky one. While there is a kind of eyewitness testimony recalling Weber and the children in Auschwitz, which I will elaborate on in more detail later, the accuracy of any testimony, particularly things remembered under distressing circumstances, cannot be taken for granted. Is it really possible that somebody actually witnessed her singing in the gas chambers, since nobody who entered would have survived? The source of Weber's final performance of "Wiegala" is anything but conclusive. There is no way of knowing if it really happened this way - or happened at all.

However, it is not only the context of this final sounding of Weber's lullaby that has underlying sources we cannot prove. We are also unsure about the texts themselves. In keeping with the questionable origins of the story is a certain ambiguity regarding the surviving manuscripts of Weber's music. As we shall see, extant arrangements of "Wiegala" and other tunes attributed to the songwriter are somewhat arbitrary. However, the mere existence of the "gas chamber narrative", and the fact that it has found its way to presentday audiences, charges "Wiegala" with meaning that aims to add a darker, more desperate side to its apparent simplicity.

In the following, I will set out to ask some central questions about the Ilse Weber phenomenon: How and why have her songs and poems found their way into today's music scene, and to what effect? What are the reasons for the radically differing versions of the music ascribed to Ilse Weber, and how does this play into the modelling of manifold notions of Terezín by individual performers? On what basis do we add to the songs, transform them, and make them our own? What conclusions, if any, can we draw both about the music and the composer based on the material available, and what are some of the wider issues of Terezín music today?

There are manifold ways to attempt answers to these questions. However, my main argument shall be that the popularity of Ilse Weber's music in Terezín commemorations is directly related to the scarce and often unverifiable sources we have, which give room for performers to add meaning, and to model "their own Ilse". Of course, the notion of re-imagining a historic site by adding to the material at hand applies much more broadly to all kinds of retrospectives. Yet, as we shall see, Ilse Weber's case is a particularly powerful one in this regard because the places her works were created and performed

Ulrike Migdal in Terezin/Theresienstadt, CD liner notes (Berlin: Deutsche Grammophon, 2008), pp. 10-11. 
in - Terezín and presumably Auschwitz - do not lend themselves to straightforward and uncomplicated truths. Nonetheless, more often than not, her tunes are appropriated to do just that: to tell a simplified sentimental story about a woman who found herself in a horrific place.

Before investigating Ilse Weber and her Terezín-songs in more detail, it is useful to outline some of the functions of the ghetto itself, which, after all, provided the context for her texts and music.

\section{A Potemkin Village}

The ghetto or Durchgangslager Terezín, which accommodated a large number of educated and formerly well-respected Jews, amongst them composers, writers, conductors, directors and visual artists, was selected to serve as propaganda tool, as a place through which the Nazis could demonstrate to the outside world that they made possible a culturally vibrant and otherwise "good life" for Jews. All of this, of course, was part of a plan to deceive the Swiss delegates of the International Red Cross who visited Terezín on 23 June 1944. In the months before their appearance, the ghetto underwent "beautification" and also prepared for the production of a propaganda film titled Theresienstadt: Ein Dokumentarfilm aus dem jüdischen Siedlungsgebiet. ${ }^{33}$ The film was to serve as a document to the outside world to give a false image of how idyllic a place a ghetto or concentration camp indeed was. According to a number of testimonies, during these months in 1944 prisoners were relatively free to follow cultural activities such as participating in concerts, opera or theatre productions and sports events. ${ }^{34}$ The inmates were allowed to schedule up to four concerts every day, and these and other activities of the Freizeitgestaltung (leisure time organisation) were welcomed by the Nazis as part of a strategy to demonstrate to the world what a cultural site Bad Theresienstadt, as they cynically called it, was. ${ }^{35}$

What exactly this freedom meant for the individual is hard to say. We do have testimonies from survivors like Ruth Elias, who heard many concerts and describes a considerable change of the everyday ghetto life. ${ }^{36}$ Nonetheless, we cannot assume that everyone was affected in the same way. However, the fraudulent construct of the Nazis paradoxically provided a niche for creativity, and perhaps even hope for the oppressed. Thus, the ghetto became a Potemkin Village during the summer of 1944. Although the inmates were forced

33 Karel Margry, “Theresienstadt (1944-1945): The Nazi propaganda film depicting the concentration camp as paradise,” Historical Journal of Film, Radio and Television 12, No. 2 (1992): 145-162.

34 See interviews with Alice Herz-Sommer and Coco Schumann in Refuge in Music: Theresienstadt, Dorothee Binding, Benedict Mirow, dir., DVD (Berlin: Deutsche Grammophon, 2013).

35 On Freizeitgestaltung see Ulrike Migdal, Und die Musik spielt dazu: Chansons und Satiren aus dem KZ Theresienstadt (München: Piper, 1986).

36 Ruth Elias, Die Hoffnung erhielt mich am Leben: Mein Weg von Theresienstadt und Auschwitz nach Israel (München: Piper, 1988), 120. 
to participate in creating a fake image of their everyday reality, a number of them did have a better and culturally richer life than any of those who found themselves at Auschwitz or another concentration camp, or war-torn places in general. Ruth Elias, who survived both Terezín and Auschwitz, remembers that the first concert she heard in the ghetto was "one of my most festive concerts I was ever allowed to listen to." ${ }^{37}$ Against all odds, Terezín became a grotesque kind of home to a number of its culturally active residents during the time of its so-called beautification. Thus, the fake reality created by the Nazis became real to some, even if only for a short while. Most of the participants of the Theresienstadt documentary were deported to Auschwitz shortly after the shooting was finished. ${ }^{38}$

\section{Ilse Weber and the "Wiegala myth"}

As a consequence of Terezín's special status, a large number of art works survived the war, including music manuscripts, poetry, letters, and drawings. Music composed or performed in the ghetto is central to many of the current attempts to reflect and rework its history. Krása's opera for children, Brundibár, is of course one of the more prominent examples. Others are instrumental pieces along the lines of the Second Viennese School such as Gideon Klein's Piano Sonata, cabaret songs like "As if" by Leo Strauss, or the simple tunes by Ilse Weber. Thus, we may ask: if anything from "serious" art music to dark-humoured cabaret may be found among the music composed in Terezín, how is it that the nostalgic and perhaps even naïve nature of a song like "Wiegala" is often foregrounded? ${ }^{39}$

In the liner notes to the 2008 CD Terezin mentioned above, Ulrike Migdal writes that Weber's songs "in their simplicity and heartfelt inwardness [...] are amongst the most moving works written in Theresienstadt." As noted earlier, she connects her observation with the statement that "Ilse Weber voluntarily went to her death together with the sick children from the camp. Eyewitnesses report that in the gas chambers, she sang her song, 'Wiegala' (Lullaby), with the Theresienstadt children." ${ }^{40}$ Yet, who were these eyewitnesses?

The likely source for this story is a passage from the book Ilse Weber: Wann wohl das Leid ein Ende hat, also written by Migdal, with the following recollection by a surviving friend of the Weber family from Ostrava/Ostrau of Ilse's arrival in Auschwitz together with a number of children from the sick ward (his identity is not further specified):

Sometime in the autumn of 1944, I saw a group of ten to fifteen children that had just been transported here. Ilse was among them and tried to comfort the little ones. "Is it true that we may take a shower after the journey?" she asked. I did not want to lie, and answered: "No,

\footnotetext{
37 Ibid., 104. Translation: Mirjam Frank

38 Margry, "Theresienstadt (1944-1945)," 146.

39 Songs by Krása, Haas and Ulmann of course do not explicitly address Terezín itself, but the musical language of their pieces is much more jarring and unsettling.

40 Migdal in Terezin/Theresienstadt, 10-11.
} 
this isn't a bathroom, it is a gas chamber, and I will give you the following advice: I have often heard you sing in the sick ward. Enter the gas chambers as fast as you can. Sit down with the children and start singing. Sing what you have always sung with them. This way, you will inhale the gas more quickly. Otherwise, you'll be trampled to death once everyone starts to panic.” Ilse's reaction was strange. She laughed, somehow absent-mindedly, hugged one of the children and said: "So we won't shower then -.".

As opposed to the Grammophon text we encounter the voice of an eyewitness here. Although this initially seems like clear evidence, it is information that comes to us through recollection. It is a retelling of an event that may or may not have taken place that way; we have no way of knowing.

While the story of Weber's encounter with a friend just before the gas chambers may well have happened along the lines outlined above, is it really possible that anyone could have had the chance to hear her sing inside the chambers, given that no one who once went in would have survived? According to Migdal, the family friend who told Weber to sing songs with the children was appointed by the Nazis to transport corpses from the gas chambers to the crematoria. Nonetheless, it remains unclear whether she did follow his advice and, if she did, which song(s) she chose. Yet, despite its unverifiable nature, the account of Weber singing in the gas chambers has become firmly attached to "Wiegala".

But what do we actually know about the song, the music itself? In order to illustrate how fragmentary the music sources are, I would like to investigate two of Weber's songs more closely: "Wiegala", which is one of the few songs for which we may actually have a handwritten manuscript of the melody line by Weber herself, and "Ich wandre durch Theresienstadt", which has probably been subject to more contrasting arrangements than any of her other works.

\section{"Wiegala": the manuscript and its performances}

Fig. 1: Transcription of the manuscript of "Wiegala" as found in Migdal, Ilse Weber, p. 269
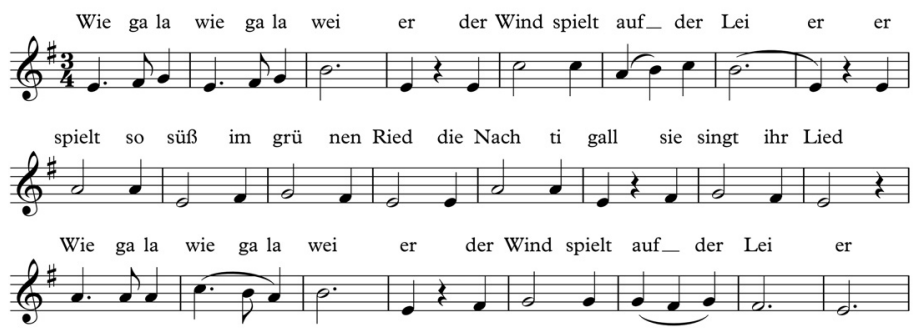

The manuscript shows that the melody of "Wiegala" was originally written in $3 / 4$ and in the key of E minor. Further, the words of the first verse are placed underneath the melody

41 Migdal, Ilse Weber, 326-327. Translation: Mirjam Frank 
line. A caption of the manuscript can be found in Ulrike Migdal's book Ilse Weber: Wann wohl das Leid ein Ende hat, and seems to have been verified as Weber's own handwriting. ${ }^{42}$ From the information given in the score, we cannot draw conclusions about how the tune was harmonized, or what tempo and instrumentation might have been like.

A literal performance of this manuscript, absent any accompaniment or indications of harmony, may have sounded like a 2014 recording by Delilah Gutman, an Italian musician and composer. ${ }^{43}$ We get a certain sense of fragility and perhaps even loneliness in Gutman's performance because the lack of accompaniment leaves the melody "hanging"; it is devoid of a foundation, as it of course would have been had Weber sung it in the gas chambers. Gutman chooses a relatively slow tempo and often decelerates or even pauses, which makes her performance somewhat eerie because it interrupts the rocking motion of the lullaby. Although simple and straightforward at first, Gutman's version also suggests solitude and disruption. Can we thus hear Terezín somewhere behind the simple tune, or is such an association a mere figment of our imagination, after having been informed about the song's background? Do the recurring downward leaps of a fifth, from B back to its E minor tonic, enforce a darker, more desperate mood? Aside from musical considerations, the song's last line "how still the world is" can of course also be read as a metaphor for death and forgetting. Might we thus say that Gutman's recording provides us with an authentic representation of "Wiegala", with the real Ilse, because she more or less closely sticks to what we find on the page and the fact that there certainly was no guitar available in the gas chambers? Or may her performance perhaps lend itself all too easily to notions of loneliness and sorrow, as if intended to create a present-day memorial?

42 I learned from several sources (among them Weber's son Hanuš and Ulrike Migdal) that all letters and manuscripts were donated to Yad Vashem by Hanuš. Even after multiple requests I have not been able to access more than four digitized files. Thus, the current location of the music and other manuscripts I am looking for is unknown to me. It has therefore been impossible for me to substantiate Migdal's claim of the handwritten "Wiegala" score by means of the sources available to me. The mentioned manuscript as well as any other handwritten sources seem inaccessible at this point. The original files I was able to investigate were typewritten (Weber often mentioned her preference for the typewriter over the use of pens in letters to her friend Lilian). Ulrike Migdal included in her book a last postcard written by Weber from Terezín. Since she chose block letters here, a comparison to the supposed manuscript (cursive) seems impossible. Addition (15 December 2015): After the submission of this article and three previously made attempts to obtain information from Yad Vashem regarding Ilse Weber's Nachlass, I finally managed to get information about the files containing manuscripts and other material. Given the short notice, I have not evaluated or even received any of it yet, but am looking forward to doing so and presenting any issues raised by these documents at some point in the future. Although I did not have a chance to look at all of this material when I worked on my article, I still suspect the collection to be fragmentary, and thus still suggest that the lack of easily accessible original sources (and/or a thorough evaluation of these) present ideal conditions for the creation of all kinds of Terezín memorials by allowing for manifold notions of Ilse Weber.

${ }^{43}$ Italya Isola Della Rugiada Divina, Delilah Sharon Gutman, Rephael Negri, perf., CD (Milan: Stradivarius, 2014). 
Deutsche Grammophon's Terezin with Anne Sofie von Otter as singer of "Wiegala" is perhaps the most widely known release of Ilse Weber's music. Even though the arrangement made for the renowned Swedish mezzo-soprano goes far beyond the information provided by the manuscript, it carefully considers possible "authentic performance practice" by using a guitar as sole instrument of accompaniment. Ruth Elias for instance, who became a close friend of Weber's in Terezín, recalls how the young songwriter and poet managed to smuggle a guitar into her so-called Kumbalek: ${ }^{44}$

A lute (which is what Ruth Elias called Ilse's guitar) had a special place on one of the walls in her Kumbalek, which one of the Czech gendarmes had "filched" for her, i.e., he had smuggled it into the camp..$^{45}$ Musical instruments of any kind were confiscated as "contraband" during the first years of the ghetto, owning them was strictly prohibited. But Ilse was lucky that her Kumbalek was never searched by the SS, for had they discovered this lute, she would have immediately received orders for the East-transport. [...] It may sound paradoxical, but we spent unforgettable hours in Ilse's Kumbalek, in which she sang songs with the lute. ${ }^{46}$

According to the above, it thus seems likely that the songs Weber wrote in Terezín were accompanied by guitar (or perhaps, as Elias called it, a lute, which may once more challenge our interpretation of Weber's music). Of course, we still cannot know what Weber's singing voice and style sounded like, and how she would have harmonized the piece. In contrast to Gutman, von Otter's lullaby stays more true to what we imagine its original, traditional use to be: the tempo is faster and steadier in a way that allows the piece to flow. Also aided by the evenly strummed chords in the guitar accompaniment, this "Wiegala" could indeed rock a baby to sleep. Von Otter sings the tune with sensitivity to the musical demands, but still manages to present "Wiegala" somewhat matter-of-factly, i.e., without sentimentality, without adding dramatic layers to hint at the song's suggested backstory. This assessment, of course, is a result of my own subjective listening, and other listeners might have different views.

44 A Kumbalek is a tiny room, which Weber shared with her sister-in-law, Erna. See Migdal, Ilse Weber, 322-323.

45 Annotation in brackets inserted by Ulrike Migdal.

While it is most likely that Weber, who was largely a self-taught musician, had a guitar at her disposal in Terezín, it still seems odd that Elias would refer to it as a lute. A photograph taken in 1928 shows Weber with a lute (Migdal, Ilse Weber, p. 2). Of course, it must have been a different instrument than the one she used in Terezín. In letters Weber wrote to her friend Lilian in Sweden, she also talks about playing the lute. However, the kind of lute shown in the 1928 picture is played and tuned like a guitar, and merely adopts the visual aspects of the early instrument. This "quasi-guitar" seems to have been rather common around the time (I would like to thank lutenist Axel Wolf for his assessment of the matter). We also know that Weber was given a balalaika by a Gypsy when she was a young woman. She thus might have had access to yet another style of music making.

Ruth Elias quoted in Migdal, Ilse Weber, 323. Translation: Mirjam Frank. 
Knowing that Weber played her songs on a guitar does of course not answer the question of how she might have performed them had she had more instruments at her disposal. A recording suggesting yet another approach to interpreting "Wiegala" is Bente Kahan's from her album Stimmen aus Theresienstadt (voices from Terezín). Kahan is a Norwegian cabaret singer who grew up in Tel Aviv and New York. She made herself known as an artist committed to keeping up and continuing the traditions of European Jews. ${ }^{47}$ For this reason, it is not surprising that the arrangements and instrumentation of songs presented in her album allude to Jewish folk music, particularly klezmer styles. In addition to the guitar, we also hear a violin part that is both used to complement the harmony and as an independent voice. Kahan sings the lullaby a fourth down from its original key, which allows her to employ the speech-like vocal quality often found on the theatre stage because the singer can stay in chest voice. Stylized glottal stops and a heightened sense of emotive expression underline the "folksiness" inherent to her interpretation. Like Gutman's solo recording, Kahan's "Wiegala” has a much more dramatic turn to it than von Otter's. The singer presents us with a theatrical, colourful version of Ilse Weber, one that we might imagine on the cabaret stages of Terezin, and thus in line with the supposedly original version of another one of Weber's songs, "Ich wandre durch Theresienstadt", as will be shown later. Most striking however is the fact that, unlike any other performance, Kahan's changes the metre from a waltz to common time. ${ }^{48}$ Weber's surviving son Hanuš was involved in compiling the liner notes of this particular album, and as far as I understand from an email conversation I had with him in December 2014, he is on friendly terms with the Norwegian singer. Unfortunately, my attempts to get in touch with Kahan herself in order to enquire about the change of metre and her arrangements of Weber's song more generally have remained unsuccessful. We may consider the possibility that she did not have access to the autograph discussed above at the time the album was produced in 1997, but perhaps either heard a rendition of the song by someone else, or encountered a copy made by a survivor of Terezín after the war.

Almost all of the other recordings of "Wiegala" I could find were made in 2008 or later, which is when Deutsche Grammophon released Terezin and Ulrike Migdal published her book with the caption of the "Wiegala" manuscript. Assuming that Kahan might have used a score or recording that was brought to her by one of Weber's surviving inmates after the war, how would we treat such a source compared to "the original"? Is it possible at all that a transcription from someone else's memory might be more "authentic" than a composer's own notation? We must keep in mind that Ilse Weber was a poet and writer of folk tunes, not a composer of classical art music. Concepts like accuracy and detail seem much more flexible here. Who knows if the composer always cared to follow her own manuscript? Maybe she even sang it in common time herself from time to time?

\footnotetext{
47 "The official page of Bente Kahan," <www.bentekahan.eu>.

48 Bente Kahan, Stimmen aus Theresienstadt: Lieder nach Gedichten von Ilse Weber \& Songs aus den Kabaretts (Dortmund: Pläne, 1997).
} 
From Elias, we also know that the songwriter was a keen improviser, which may mean that different "Wiegalas" might have already existed then. ${ }^{49}$

\section{The concept of Terezín music: "Ich wandre durch Theresienstadt"}

Music composed in Terezín is almost exclusively performed in memorial concerts today; concerts which devote themselves to a hearing of the music through the historic lens of the Holocaust. We do not hear songs like Weber's paired with compositions by Brahms, Schubert or Bach. Instead, we hear them as a re-enactment of the creative efforts that were made at the same time as others went into gas chambers. Through testimonies, we know that the soundscape of Terezín was by no means exclusively defined by the pieces we hear in many memorial concerts today. Indeed, an "authentic" Terezín performance could have included pieces by Bach, Beethoven and Mozart, alongside cabaret and opera productions, folk music sessions and jazz concerts. ${ }^{50}$ Of course, the question remains what an authentic Terezín performance might be and whether we would want to re-create it.

As is perhaps the case with all commemorative events, there can be a danger of projecting sentimentality and perhaps even nostalgia into a programme consisting of music exclusively written in camps, nestled in its crass historic background. In order to illustrate my concern here, I would like to point to Ute Lemper's emotionally charged performance of Weber's "Ich wandre durch Theresienstadt" (I wander through Terezín). ${ }^{51}$

First of all, just like with "Wiegala", there are a number of choices that can be made when performing the song. Composer and arranger Winfried Radeke published two versions in his 2008 edition of songs to poems by Ilse Weber. ${ }^{52}$ All of the texts in this volume were written by Weber herself, the origins of melodies and accompaniments however are mostly unclear to the reader. ${ }^{53}$ Rather surprisingly, the version that is directly attributed to Weber has a march-like accompaniment. The second-beat triplets add a tone of mockery or sarcasm to a text that talks about a walk through Terezín with "the heart as heavy as lead" (Ex. 2 bars 1 and 5), somewhat reminiscent of the grotesque cynicism of Berlin cabaret.

49 Elias in Migdal, Ilse Weber, 323.

50 See Joza Karas, Music in Terezin 1941-1945 (Stuyvesant, N.Y.: Pendragon Press, 1985), 37-62.

51 “Holocaust Memorial Concert," Rai 5, Rome 26 January 2015, accessed via YouTube <https://www. youtube.com/watch?v=1LZ_4DWY09w>.

52 Winfried Radeke, ed., Ich wandre durch Theresienstadt: Lieder für Singstimme und Klavier (Berlin: Bote \& Bock, 2008), pp. 6, 16.

53 The editor, Winfried Radeke, explains in a foreword that most of the sources of the accompaniments to Weber's songs are unidentifiable. Yet, it is not always apparent to the reader where exactly he (or someone else) added to Weber's poems and/or manuscripts. 
Fig. 2: "Ich wandre durch Theresienstadt" as composed by Ilse Weber, according to Radeke, Ich wandre durch Theresienstadt, p. 6

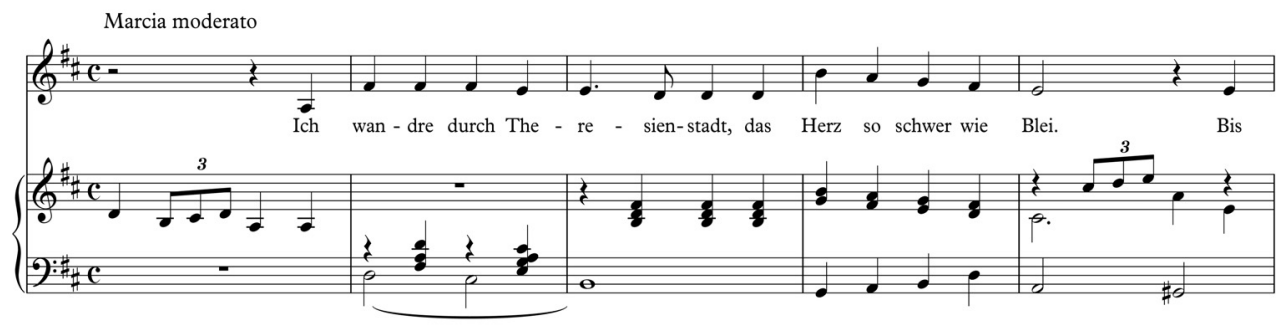

The song as arranged by Radeke imitates guitar-arpeggios, perhaps deriving from our knowledge that Weber had a guitar in the ghetto. Nonetheless, the change of rhythmic action in the accompaniment here of course suggests an atmosphere of resignation, which stands in stark contrast to the rather provocative, march-like variant attributed to Weber.

Fig. 3: "Ich wandre durch Theresienstadt" as arranged by Radeke in Ich wandre durch Theresienstadt, p. 16

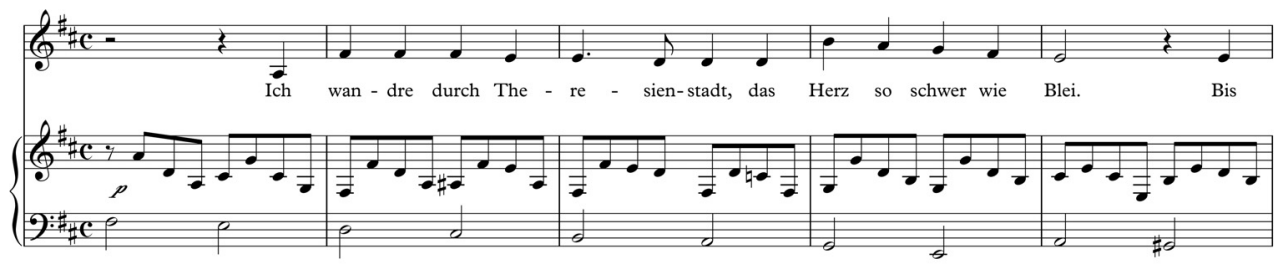

Ute Lemper's arrangement is much more like the one provided by Radeke, and she heightens the sentimentality of the blissfully rippling arpeggios we hear from the piano by giving an introduction to the song and calling it "a proof of life, a proof of the spirit, the compassion and the love of Ilse Weber and all those others [...]”. Lemper closes with the words "[...] never ever again", alluding to a time in history that has passed and left behind its terror. Her performance has the potential to suggest that we are a morally superior audience - because we "understand". ${ }^{54}$

Lemper's audience learns little about the context, i.e., the actual circumstances under which the songs were written, performed and passed on. Instead, we are presented with the larger concerns: the camp, the death of millions. In the case of "Ich wandre durch Theresienstadt", we hear a sweet and mellow tune and, at the same time, are lead to think about gas chambers and crematoria. The chasm between these two thought processes could not be bigger and the kinds of reactions that are triggered in an audience by the juxtaposition of such contrasting images are variable, ambiguous and poorly understood.

54 “Holocaust Memorial Concert," Rai 5, Rome 26 January 2015. 
Yet, despite the number of performances and recordings that were made of "Ich wandre durch Theresienstadt", we do not even know whether the song was actually composed by Ilse Weber herself. The first, march-version is attributed in its entirety to Ilse Weber by the editor Winfried Radeke. However, it is known that Weber was primarily a guitarist (or "lutenist") and not a pianist, which makes it rather unlikely that the accompaniment was written by her. Deutsche Grammophon attributes only text and melody to Weber. The liner notes to Stimmen aus Theresienstadt only credit her as the writer of the lyrics. Moreover, we have no way of knowing when the songs of Weber were written down, how and by whom they were remembered, or whether they might be post-war compositions altogether as long as original manuscripts and other sources from the Nachlass remain unlocatable - or lost.

\section{Why Ilse Weber?}

As demonstrated above, the case of Ilse Weber is a particularly interesting one regarding the "Terezín commemoration concerts". Reconstructions of her music are anything but straightforward, owing to the small amount of surviving source material. According to Radeke, 11 songs survived, eight of which were brought to us by Weber's fellow inmates after the war. Apart from "Wiegala", there supposedly are manuscripts of "Schlaf, mein Püppchen" and "Emigrantenlied" ${ }^{55}$ Information provided by Ulrike Migdal, who perhaps has more insight into the texts and music written by Ilse Weber than anyone else, states that only eight songs survived, and the songwriter's own son, Hanuš, also mentioned eight songs to me in an email. However, the pieces he lists slightly differ from Migdal's account. ${ }^{56}$ Although the state of Weber's song collection is rather fragmentary, we also have to keep in mind that her pieces were not so-called art songs, which are notated in a far more detailed manner, offering much less freedom to the performer. If anything, they belong in the category of folk music or popular song, which means that, with or without a complete surviving manuscript, the songs are much more likely to be adjusted by the performer. Thus, the nature of Weber's songs, and the fact that their origins remain unclear to us, somehow make Ilse Weber ungraspable as both woman and songwriter, and an ideal figure for the creation of manifold notions of Terezín.

On the surface it seems that through the inwardness and simplicity of songs like "Wiegala" and "Ich wandre durch Theresienstadt", we as an audience are granted access

55 Radeke, Ich wandre durch Theresienstadt, 3.

56 In Ilse Weber, p. 338, Migdal lists "Ich wandre durch Theresienstadt", "Und der Regen rinnt”, "Ade, Kamerad”, "Kleines Wiegenlied”, "Wiegenlied (Ukolébavka)”, "Emigrantenlied”, "Gebet (Modlitba)" and "Wiegala". Hanuš Weber lists the same songs with the exception of "Gebet". Instead, he names a piece called "Dobrý den”. Further, Migdal informs us that compositions by Ilse Weber to the texts of these eight songs have survived, but we do not learn what the scores might look like. Migdal also states that a lot of material, perhaps including music manuscripts, was confiscated (and destroyed) during house searches in the communist era in Prague. 
to the inner world of the songwriter Ilse Weber. Although none of us had to experience the inhumanity of WW2 in Central Europe, we can all somehow connect to a nostalgic longing for a place of hope, calm and peace. In the two pieces discussed, Weber does not give a vivid account of the horrific reality at Terezín, and, accompanied by the "gas chamber narrative", offers us a much more universal notion of Weltschmerz than a graphic depiction would do. Depending on how it is harmonized, a simple song like "Wiegala", that seems to be caught in its minor key, alongside imagery of the moon as lantern, the wind that plays on the lyre and the stillness of the world, is both sad and consoling at the same time.

At the 2014 Canberra International Festival of Music, for instance, a programme titled Triumph of the Heart: Music from the Camps included two pieces by Weber, among them "Wiegala". ${ }^{57}$ A member of the audience expressed the effect this particular song had on her as follows: "[...] The audience were unable to move at the end. Many, like me, sat with tears rolling down their faces as we processed what we were hearing. Chris Latham had earlier explained that this song was written for the children of Terezin as a lullaby, but that it had finally been sung to them [...] in the gas chamber at Auschwitz." ${ }^{58}$ What would their reaction have been had they not been introduced to the background story?

\section{Conclusion}

The rediscovery of Ilse Weber's songs has certainly enabled a Terezín-story that introduces a kind of simplicity and quietness into a place that is mostly associated with noise, uncertainty and existential angst. It could even be said to add a lighter, maternal facet to the Terezin canon that otherwise consists of works by male composers. Yet, the stillness and simplicity are deceptive, both in the song "Wiegala" that, as noted above, repeatedly falls a fifth back to its dark minor tonic, and in the way singular notions of Ilse Weber and Terezín are shaped.

That Weber indeed was an unusually strong and caring woman who tried to uplift the spirits of others through songs and poetry is beyond doubt. However, it becomes clear through her large collection of letters and poems that she was a much more multi-faceted woman. Weber was politically engaged and forward thinking. She was a mother of two, a writer of radio plays and poetry, and engaged in socialist thought. Further, Weber had a sharp sense for the developments in central Europe in the 1930s. ${ }^{59}$ In an interview from 2008, Weber's eldest and only surviving son Hanuš reveals that, through her letters and poems, he discovered sides of his mother he had never known, and is unsure how to

57 "Canberra International Music Festival: The Fire and the Rose," 9-18 May 2014, programme, <http://issuu.com/pro-musica/docs/cimf_brochure_2014? e=0/7179221>.

58 Post by "Wild Voices Music Theatre" seen on Facebook <https://www.facebook.com/WVMusicTheatre/posts/307762059349157>, 13 May 2014.

59 Migdal, Ilse Weber, 13-31. 
reconcile them. ${ }^{60}$ We might take Hanuš's ambivalence, along with the many versions of "Wiegala", as a caution against creating a unitary picture of Weber and, instead, embrace a multi-faceted persona comprising contradictions and unresolved questions.

Although nostalgia was certainly one of many survival modes within the walls of Terezín, we have to remind ourselves that Terezín itself must never become a place of nostalgia for us. Many of the performers introduced above have done important and valuable work. They make us listen to the words of a woman who was silenced in Auschwitz in 1944. Her music deserves to be heard in all kinds of contexts, and certainly does not have to be restricted to memorial events. "Authenticity", of course, can by no means be a criterion for today's performances. Not only because a re-enactment of Terezín cannot be in anybody's interest, but also to keep her music alive and prevent it from becoming a museum exhibit. It may well speak for itself. Daniel Hope poignantly points out that "this music does not need its history; but has it." ${ }^{1}$

Yet, as we have seen, "Wiegala" or "Ich wandre durch Theresienstadt" seem to lend themselves particularly well to evoking emotional responses. Sentimentalizing Weber's lullaby poses the danger of transforming Terezín itself into a nostalgic place for its audiences. Of course, it is hardly a coincidence that "Wiegala" is readily used for such a transformation, for lullabies in general function particularly well regarding softer and more sentimental appropriations. This form of nostalgia, in turn, creates a mirror image of what the Nazis had had in mind: a model concentration camp for visitors. Because we are not made aware that the compositions we are hearing have been altered and given different meanings ever since they were found and sung for the first time, memorial events may run the risk of creating yet another Potemkin Village, a "Potemkin Concert", a place that avoids direct and uncomfortable confrontation with a historic event that will always pose more questions than it can provide answers. Some of these memorials may even provide a platform for moral whitewashing, perhaps blended with a little bit of voyeurism, at the expense of (musical) variety. Terezín served as a model camp in 1944 to create a false image of concentration camp reality; Terezín serves as a model camp today, 60 years after the war, where some of the ostensibly most sentimental and accommodating tunes are a vehicle for nostalgic sentiments in a world where we would do well to make such performances relevant for present times, where - to some - genocide and war are a present reality.

\footnotetext{
${ }^{60}$ Interview conducted by Yasemin Ergin for NDR Kulturjournal; accessed via <http://www.zwockhaus. de/weber.php>.

${ }_{61}$ Refuge in Music: Theresienstadt, Berlin 2013, [50:00]. Translation: Mirjam Frank
} 


\title{
The Lullaby of Ilse Weber: Terezín as a Mirror Image
}

\begin{abstract}
Although Ilse Weber's compositions have become central to the "Terezín canon", very few of her musical manuscripts are available. My study argues that the lack of sources actually serves Weber's popularity, as her Terezín songs can be tailored to the needs of individual performers to represent manifold notions of Terezín. Furthermore, my research juxtaposes Terezín's current status as a memorial site with its original function as a "Potemkin Village." Considering that much of the complexity of Terezín's original soundscape has been ignored or suppressed, I argue that it has become a simplified mirror image of the "model ghetto" it originally was.
\end{abstract}

\section{Ukolébavka Ilse Weber: Terezín jako obraz v zrcadle}

\begin{abstract}
Abstrakt
Ačkoliv se skladby Ilse Weber staly středem „terezínského kánonu“, jejich rukopisy jsou stále těžko dostupné. Studie tvrdí, že právě tato skutečnost přispívá k popularitě Ilse Weber, nebot interpretace jejích písní takto zůstává otevřená různým pojetím, potažmo představám reprezentace Terezína. Studie dále srovnává současný status Terezína jako pamětního místa s původním určením tzv. Potěmkinovy vesnice. S ohledem na současný reduktivní obraz hudebního života $\mathrm{v}$ Terezíně studie nachází paralely se zjednodušeným obrazem daného místa jako „vzorového ghetta“ v minulosti.
\end{abstract}

\section{Keywords}

Auschwitz; Freizeitgestaltung; Ilse Weber; Lullaby; Memorial; Mirror Image; Potemkin Village; Sentimentality; Terezín/Theresienstadt.

\section{Klíčová slova}

Auschwitz (Osvětim); Freizeitgestaltung; Ilse Weber; ukolébavka; památník; obraz v zrcadle; Potěmkinova vesnice; sentimentalita; Terezín/Theresienstadt. 